\title{
Mutant $\alpha$-Synuclein Overexpression Induces Stressless Pacemaking in Vagal Motoneurons at Risk in Parkinson's Disease
}

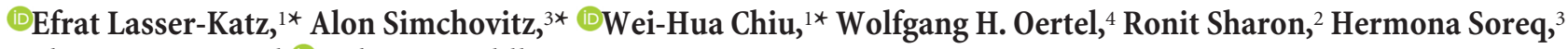 \\ Jochen Roeper, ${ }^{5}$ and ${ }^{1 D}$ Joshua A. Goldberg ${ }^{1}$ \\ ${ }^{1}$ Department of Medical Neurobiology and 2Department of Biochemistry and Molecular Biology, Institute of Medical Research Israel-Canada, The Faculty \\ of Medicine, and ${ }^{3}$ The Edmond and Lily Safra Center for Brain Sciences and the Institute of Life Sciences, The Hebrew University of Jerusalem, 9112102, \\ Jerusalem, Israel, ${ }^{4}$ Department of Neurology, Philipps-University Marburg, 35043 Marburg, Germany, and 5 Institute of Neurophysiology, Neuroscience \\ Center, Goethe-University, 60590 Frankfurt, Germany
}

$\alpha$-Synuclein overexpression (ASOX) drives the formation of toxic aggregates in neurons vulnerable in Parkinson's disease (PD), including dopaminergic neurons of the substantia nigra (SN) and cholinergic neurons of the dorsal motor nucleus of the vagus (DMV). Just as these populations differ in when they exhibit $\alpha$-synucleinopathies during PD pathogenesis, they could also differ in their physiological responses to ASOX. An ASOX-mediated hyperactivity of SN dopamine neurons, which was caused by oxidative dysfunction of Kv4.3 potassium channels, was recently identified in transgenic (A53T-SNCA) mice overexpressing mutated human $\alpha$-synuclein. Noting that DMV neurons display extensive $\alpha$-synucleinopathies earlier than SN dopamine neurons while exhibiting milder cell loss in PD, we aimed to define the electrophysiological properties of DMV neurons in A53T-SNCA mice. We found that DMV neurons maintain normal firing rates in response to ASOX. Moreover, Kv4.3 channels in DMV neurons exhibit no oxidative dysfunction in the A53T-SNCA mice, which could only be recapitulated in wild-type mice by glutathione dialysis. Two-photon imaging of redox-sensitive GFP corroborated the finding that mitochondrial oxidative stress was diminished in DMV neurons in the A53T-SNCA mice. This reduction in oxidative stress resulted from a transcriptional downregulation of voltage-activated (Cav) calcium channels in DMV neurons, which led to a reduction in activity-dependent calcium influx via Cav channels. Thus, ASOX induces a homeostatic remodeling with improved redox signaling in DMV neurons, which could explain the differential vulnerability of SN dopamine and DMV neurons in PD and could promote neuroprotective strategies that emulate endogenous homeostatic responses to ASOX (e.g., stressless pacemaking) in DMV neurons.

Key words: acetylcholine; homeostasis; Lewy pathology; multiphoton microscopy; neurodegeneration; oxidative stress

\section{Significance Statement}

Overexpression of mutant $\alpha$-synuclein causes Parkinson's disease, presumably by driving neurodegeneration in vulnerable neuronal target populations. However, the extent of $\alpha$-synuclein pathology (e.g., Lewy bodies) is not directly related to the degree of neurodegeneration across various vulnerable neuronal populations. Here, we show that, in contrast to dopamine neurons in the substantia nigra, vagal motoneurons do not enhance their excitability and oxidative load in response to chronic mutant $\alpha$-synuclein overexpression. Rather, by downregulating their voltage-activated calcium channels, vagal motoneurons acquire a stressless form of pacemaking that diminishes mitochondrial and cytosolic oxidative stress. Emulating this endogenous adaptive response to $\alpha$-synuclein overexpression could lead to novel strategies to protect dopamine neurons and perhaps delay the onset of Parkinson's disease.

\section{Introduction}

The formation of $\alpha$-synuclein-laden intracellular inclusions in the brain, called Lewy pathologies (LPs), is a hallmark of Parkin-

Received April 1, 2016; revised 0ct. 20, 2016; accepted 0ct. 27, 2016.

Author contributions: E.L.-K., A.S., W.-H.C., R.S., H.S., J.R., and J.A.G. designed research; E.L.-K., A.S., W.-H.C.,

J.R., and J.A.G. performed research; W.H.O. contributed unpublished reagents/analytic tools; E.L.-K., A.S., W.-H.C.,

J.R., and J.A.G. analyzed data; E.L.-K., H.S., J.R., and J.A.G. wrote the paper. son's disease (PD; Lewy, 1912; Braak et al., 2004). Braak and colleagues proposed that a subset of neuronal populations [e.g., vagal cholinergic motoneurons (DMVs), locus ceruleus (LC) adrenergic neurons, and substantia nigra $(\mathrm{SN})$ dopamine neurons] 
acquires these LPs in a stereotypical temporal order ranging from premotor stages (DMV) to full clinical PD (Stage III), where loss of SN dopamine neurons is sufficient to cause the classical, levodoparesponsive motor symptoms (Braak et al., 2004; Seidel et al., 2015). Why certain neuronal populations are the targets of LPs and how this translates to different degrees of neurodegeneration is still not understood. Apart from sharing some potential morphological risk features (e.g., extraordinarily long nonmyelinated axonal arbors; Braak et al., 2004; Bolam and Pissadaki, 2012; Pissadaki and Bolam, 2013), these neuronal populations also share a metabolically costly electrophysiological phenotype, which is characterized by autonomous pacemaker firing, during which large amounts of activitydriven calcium enters the neuron via voltage activated (Cav) calcium channels (Surmeier et al., 2011). Given the low cytosolic calcium buffering in DMV neurons, calcium ions are readily taken up by the mitochondria, where they elevate oxidative stress, as monitored by optical redox sensors, such as mitochondrial targeted redox-sensitive GFP (mito-roGFP; Dooley et al., 2004; Guzman et al., 2010; Surmeier et al., 2011; Goldberg et al., 2012; SanchezPadilla et al., 2014). It is currently an open question whether this precarious electrical phenotype shared by vulnerable neurons has a physiological function [e.g., by allowing fast switching between tonic and burst states in vivo (Paladini and Roeper, 2014)]. Because there is ample evidence that LPs or $\alpha$-synuclein overexpression (ASOX) are linked to elevated levels of oxidative stress (Hsu et al., 2000; Goedert, 2001; Sherer et al., 2001; Parihar et al., 2008), it might - by escalating the already high levels of activity-driven oxidative stress or possibly by potentiating Cav channels (Adamczyk and Strosznajder, 2006; Hettiarachchi et al., 2009)_have a particularly detrimental impact on these pacemaker neurons by combining innate (i.e., electrical phenotype) with acquired vulnerabilities due to toxic $\alpha$-synuclein aggregates.

In accordance with this scheme, a recent study showed that mutant ASOX exacerbates the "stressful pacemaking" of SN dopamine neurons by speeding up their firing both in vivo and in vitro (Subramaniam et al., 2014). For SN dopamine neurons in middle-aged A53T-SNCA mice, this elevated discharge was caused by oxidative dysfunction of Kv4.3 channels, which normally dampens the pacemaker rate (Liss et al., 2001). In that

support of the Edmond and Lily Safra Center for Brain Sciences. The CMV-mito-roGFP adeno-associated virus was contributed by Dr. Jim Surmeier (Northwestern University). We thank Prof. Yoel Yaari and Dr. Alex Binshtok (the Hebrew University of Jerusalem) for the use of their equipment, and Anatoly Shapochnikov for excellent technical assistance.

The authors declare no competing financial interests.

*E.L.-K., A.S., and W.-H.C. contributed equally to this work.

Correspondence should be addressed to Dr. Joshua A. Goldberg, Department of Medical Neurobiology, Institute of Medical Research Israel-Canada, The Faculty of Medicine, The Hebrew University of Jerusalem, POB 12272, Ein Kerem Campus, 9112102 Jerusalem, Israel. E-mail: joshg@ekmd.huji.ac.il.

DOI:10.1523/JNEUROSCI.1079-16.2016

Copyright $\odot 2017$ the authors $\quad 0270-6474 / 17 / 370048-11 \$ 15.00 / 0$ study, the Kv4.3 protein was upregulated in the membrane of SN dopamine neurons in A53T-SNCA mice, indicating an incomplete homeostatic response aimed at reducing the $\alpha$-synucleindriven hyperactivity. However, the role of Cav channels was not investigated. In another study, transduction of cultured dopamine cells with preformed fibrils of $\alpha$-synuclein led to elevated dendritic oxidative stress dependent on calcium flux via Cav channels (Dryanovski et al., 2013).

Motoneurons of the DMV are among the first cells to exhibit LPs (Lewy, 1912; Braak et al., 2004), suggesting that they are among particularly vulnerable neuronal populations. However, compared with the early onset and large extent of the LPs, the $30 \%$ cell loss (i.e., neurodegeneration) is relatively mild (Eadie, 1963; Seidel et al., 2010) and stands in stark contrast to the fastand in some subregions almost complete-loss of SN dopamine neurons (Kordower et al., 2013). To test whether DMV neurons respond differently to a chronic challenge of mutant $\alpha$-synuclein protein, we studied the electrophysiological properties of DMV neurons, the biophysics of Kv4.3 and Cav channels, and the redox state of DMV neurons in transgenic A53T-SNCA mouse models.

\section{Materials and Methods}

Slice preparation. Experimental procedures adhered to and received prior written approval from the Hebrew University Institutional Animal Care and Use Committee and from the German Regierungspräsidium Darmstadt. Experiments were conducted on two mouse lines that overexpress the mutated human $\alpha$-synuclein (A53T-SNCA) gene and their agematched wild-type littermate controls. Measurements of the glutathione (GSH) rescue of Kv4.3-channel activity were conducted on 6-8-monthold A53T-SNCA mice (Fig. 1, A53T-SNCA $A_{N b m}$ ) of both sexes on the 
C57BL/6J background, backcrossed for $>6$ generations from the original FVN background (Gispert et al., 2003; Subramaniam et al., 2014). Animals were deeply anesthetized with intraperitoneal injections of ketamine $(200 \mathrm{mg} / \mathrm{kg})$-xylazine $(23.32 \mathrm{mg} / \mathrm{kg})$ and perfused transcardially with ice-cold modified artificial CSF (ACSF) oxygenated with 95\% $\mathrm{O}_{2}-5 \% \mathrm{CO}_{2}$ and containing the following (in $\mathrm{mM}$ ): $2.5 \mathrm{KCl}, 125 \mathrm{NaCl}, 25$ $\mathrm{NaHCO}_{3}, 1.25 \mathrm{Na}_{2} \mathrm{HPO}_{4}, 0.1 \mathrm{CaCl}_{2}, 6.2 \mathrm{MgSO}_{4}, 2.5$ glucose, 2.96 kynurenic acid, and 50 sucrose. The cerebellum, pons, and medulla were rapidly removed, blocked in the coronal plane, and sectioned at a thickness of $240 \mu \mathrm{m}$ in ice-cold modified ACSF. Slices were then submerged in ACSF, bubbled with $95 \% \mathrm{O}_{2}-5 \% \mathrm{CO}_{2}$, and containing the following (in mM): $2.5 \mathrm{KCl}, 125 \mathrm{NaCl}, 25 \mathrm{NaHCO}_{3}, 1.25 \mathrm{Na}_{2} \mathrm{HPO}_{4}, 2 \mathrm{CaCl}_{2}, 2.1$ $\mathrm{MgSO}_{4}, 2.5$ glucose, and 22.5 sucrose. Slices then were stored at $36^{\circ} \mathrm{C}$ for $\geq 90$ min before recording. All the remaining experiments were conducted on 3-8-month-old or 11-15-month-old homozygous A53TSNCA mice (Line M83; Fig. 1, A53T-SNCA ${ }_{V l e}$; RRID:IMSR_JAX: 004479) of both sexes on the C57BL/C3H background (Giasson et al., 2002). Animals in the older age group were used regardless of whether they exhibited motor abnormalities or not. All procedures were identical except that (1) the ice-cold modified ACSF in these experiments contained the following (in mM): $2.5 \mathrm{KCl}, 26 \mathrm{NaHCO}_{3}, 1.25 \mathrm{Na}_{2} \mathrm{HPO}_{4}, 0.5$ $\mathrm{CaCl}_{2}, 10 \mathrm{MgSO}_{4}, 0.4$ ascorbic acid, 10 glucose, and 210 sucrose; and (2) the ACSF in these experiments contained the following (in $\mathrm{mm}$ ): $2.5 \mathrm{KCl}$, $126 \mathrm{NaCl}, 26 \mathrm{NaHCO}_{3}, 1.25 \mathrm{Na}_{2} \mathrm{HPO}_{4}, 2 \mathrm{CaCl}_{2}, 2 \mathrm{MgSO}_{4}$, and 10 glucose.

Slice visualization and electrophysiology. The slices were transferred to the recording chamber mounted on an upright Zeiss Axioskop fixedstage microscope and perfused with oxygenated ACSF at $32^{\circ} \mathrm{C}$. A $60 \times$, 0.9 numerical aperture water-immersion objective was used to examine the slice using standard infrared differential interference contrast video microscopy. Patch pipette resistance was typically $3-4.5 \mathrm{M} \Omega$. For wholecell current-clamp recordings and for voltage-clamp measurements of sodium conductances, the pipette contained the following (in $\mathrm{mM}$ ): 135.5 $\mathrm{KCH}_{3} \mathrm{SO}_{3}, 5 \mathrm{KCl}, 2.5 \mathrm{NaCl}, 5 \mathrm{Na}$-phosphocreatine, 10 HEPES, 0.2 EGTA, $0.21 \mathrm{Na}_{2} \mathrm{GTP}$, and $2 \mathrm{Mg}_{1.5}$ ATP, pH 7.3 with $\mathrm{KOH}(280-290$ $\mathrm{mOsm} / \mathrm{kg}$ ). For whole-cell voltage-clamp recordings of calcium currents, the pipette contained the following (in $\mathrm{mM}$ ): $111 \mathrm{CsCH}_{3} \mathrm{SO}_{3}, 12.5$ $\mathrm{CsCl}, 1 \mathrm{MgCl}_{2}, 0.1 \mathrm{CaCl}_{2}, 10$ HEPES, 1 EGTA, $0.21 \mathrm{Na}_{2} \mathrm{GTP}$, and 2 $\mathrm{Mg}_{1.5} \mathrm{ATP}, \mathrm{pH} 7.3$ with $\mathrm{CsOH}(280-290 \mathrm{mOsm} / \mathrm{kg})$. For the whole-cell voltage-clamp recordings of the Kv4.3 currents, the pipette contained the following (in mM): $135 \mathrm{~K}$-gluconate, $5 \mathrm{KCl}, 2 \mathrm{MgCl}_{2}, 10$ HEPES, 0.1 EGTA, $1 \mathrm{Li}_{2} \mathrm{GTP}, 5 \mathrm{Na}_{2}$ ATP, pH 7.35 with $\mathrm{KOH}(270-300 \mathrm{mOsm} / \mathrm{kg})$. Pipette solutions containing an additional $10 \mathrm{~mm}$ GSH were dialyzed into DMV neurons in the whole-cell configuration for testing redox modulation of Kv4.3 channels. Electrophysiological recordings were obtained with a Multiclamp 700B amplifier (Molecular Devices) or EPC-10 (HEKA). Signals were digitized at $20-100 \mathrm{kHz}$ and logged onto a personal computer with the Signal 6 (Cambridge Electronic Design), pClamp9 (Molecular Devices; RRID:SCR_011323), or Patchmaster (HEKA; RRID:SCR_000034) software.

Unilateral injection of recombinant adeno-associated viral-mediated vector. Mice were deeply anesthetized with isoflurane in a nonrebreathing system $(2.5 \%$ induction, $1-1.5 \%$ maintenance $)$ and placed in a stereotaxic frame (Kopf Instruments). Temperature was maintained at $35^{\circ} \mathrm{C}$ with a heating pad, artificial tears were applied to prevent corneal drying, and animals were hydrated with a bolus of injectable saline $(10 \mathrm{ml} / \mathrm{kg})$ mixed with analgesic ( $5 \mathrm{mg} / \mathrm{kg}$ carpofen). A total amount of $400 \mathrm{nl}$ of an adeno-associated virus serotype 9 harboring a mitochondrial targeted redox-sensitive GFP expression construct (AAV9-CMV-MTS-roGFP; $2.3 \times 10^{13} \mathrm{vg} / \mathrm{ml}$; Guzman et al., 2010; Goldberg et al., 2012; SanchezPadilla et al., 2014) was injected into the DMV under aseptic conditions. After the injection, the needle was held in the brain for 5 more minutes before it was slowly retracted. All injections were performed using a microsyringe with a stainless steel needle ( $35 \mathrm{ga}$; WPI). The coordinates of the injection were as follows: anteroposterior, $-7.5 \mathrm{~mm}$; mediolateral, $+0.33 \mathrm{~mm}$; and dorsoventral, $-4.45 \mathrm{~mm}$, relative to bregma using a flat skull position (Paxinos and Franklin, 2004).

Wide-field calcium imaging. Pipette solutions contained the following (in mM): $130 \mathrm{~K}$-gluconate, $6 \mathrm{KCl}, 8 \mathrm{NaCl}, 10$ HEPES, $2 \mathrm{Mg}_{1.5} \mathrm{ATP}, 0.05$ fluo-4, pH 7.3 with $\mathrm{KOH}(280-290 \mathrm{mOsm} / \mathrm{kg})$. After rupture of the membrane patch, $\geq 5 \mathrm{~min}$ were allowed for equilibration of the indicator between the electrode and the somatic cytoplasm. Optical measurements were made using illumination at $470 \mathrm{~nm}$ (Mightex) and a cooled electron-multiplying CCD (Evolve 512 Delta, Photometrics). Pixel size was $0.4 \mu \mathrm{m}$ and $2 \times 2$ binning was used to achieve high frame rates. Autofluorescence was corrected by subtracting the fluorescence level of a nearby region not containing any indicator-labeled process. Optical and electrophysiological data were obtained using custom-made Winfluor software (John Dempster, University of Strathclyde, UK).

Two-photon laser scanning microscopy. The two-photon excitation source was a Chameleon Ultra 2 tunable laser system $(680-1080 \mathrm{~nm}$; Coherent). Optical signals were acquired using a $920 \mathrm{~nm}$ excitation beam to excite the roGFP fluorescence. The roGFP emission $(490-560 \mathrm{~nm})$ was detected by the Zeiss LSM 7 multiphoton system. We collected $\leq 60$ frames of the roGFP signal (1.5-4 frames per second) in a single optical plane traversing the somata of the DMV neurons to determine the baseline fluorescence $(F)$ of the cell. At the end of all experiments, $2 \mathrm{~mm}$ dithiothreitol (DTT) was applied for $10 \mathrm{~min}$ to reduce the mitochondria fully so as to measure the maximal fluorescence $\left(F_{\mathrm{DTT}}\right)$, followed by 400 $\mu \mathrm{M}$ Aldrithiol (Ald) for $45 \mathrm{~min}$ to fully oxidize the mitochondria, so as to determine the minimal fluorescence $\left(F_{\mathrm{Ald}}\right)$. The relative oxidation was then calculated as $\left(F_{\text {DTT }}-F\right) /\left(F_{\text {DTT }}-F_{\text {Ald }}\right)$ (Goldberg et al., 2012).

Immunohistochemistry. Tissue preparation and the staining protocols were performed as described previously (Chiu et al., 2014). Briefly, animals were deeply anesthetized and perfused transcardially with $0.1 \mathrm{M}$ phosphate buffer (PB) following ice-cold 4\% PFA. Coronal sections of the DMV were cut at $30 \mu \mathrm{m}$ on a cryostat microtome (Leica CM1950) in antifreeze buffer (1:1:3 volume ratio of ethyl glycerol, glycerol, and $0.1 \mathrm{M}$ $\mathrm{PB})$ and stored at $-20^{\circ} \mathrm{C}$ before further analysis. The sections were preincubated in 5\% normal horse serum and $0.3 \%$ Triton X-100 in $0.1 \mathrm{M} \mathrm{PB}$ for $40 \mathrm{~min}$ after washing steps, and incubated overnight at $4^{\circ} \mathrm{C}$ with the primary antibodies [goat anti-choline acetyltransferase (ChAT), 1:100 (Millipore; RRID:AB_262156); mouse anti-human $\alpha$-synuclein, 1:1000 or 1:5000 (Thermo Fisher Scientific, RRID:AB_1954821); rabbit anti-rat Kv4.3 (1:1000; Alomone Labs, RRID:AB_2040178)]. On the second day, sections were incubated with fluorophore-conjugated species-specific secondary antibodies [donkey anti-mouse/anti-goat/anti-rat; 1:1000 (Abcam)] for $2 \mathrm{~h}$ at room temperature. Brain sections were rinsed in PBS and directly coverslipped by fluorescent mounting medium (Vectashield, Vector Laboratories). Multilabeling fluorescent immunostainings of juxtacellularly filled neurons were analyzed using a laserscanning microscope (LSM 510 Meta, Zeiss, or Fluoview FV1000, Olympus) using either a $10 \times / 0.3$ numerical aperture or a $60 \times / 1.4 \mathrm{nu}-$ merical aperture differential interference contrast lens $(10 \times$ zoom). For semiquantitative optical density analysis of the human $\alpha$-synuclein transgene expression in DMV neurons, we used ImageJ software (http:// rsbweb.nih.gov/ij/) to determine the mean immunosignal intensities of ChAT-positive regions of interest in the brainstem slices. We used three confocal slices through the DMV from each mouse with a total of three wild-type and three A53T-SNCA mice for the analysis. Each confocal slice was a collapsed $z$-stack of 10 adjacent $1-\mu$ m-thick optical slices chosen so that they arose primarily from within individual DMV neurons. Thus, while it is not possible to rule out the possibility that some of the fluorescence arises from other processes (e.g., glia), the majority of the signal is confined to ChAT-immunopositive neuronal somatodendritic domains in the DMV.

RNA extraction from mouse brain slices. The DMV was microdissected out from $240-\mu \mathrm{m}$-thick brain slices. RNA extraction, cDNA synthesis, qPCR, and primer design were described previously (Cooper et al., 2015). The data were obtained using Bio-Rad CFX Manager 3.0 software. Also, for each primer pair, a dilution curve was created to calculate primer efficiency, which was then used to recalculate the expression results. Fixed values were normalized to the neuronal-specific TUBB3 as a neuronal marker.

Drugs and reagents. For recording of autonomous discharge, we used a mixture of synaptic receptor blockers containing the following (in $\mu \mathrm{M}$ ): 50 D-APV, 5 NBQX, 10 SR 95531, 1 CGP 55845, 10 mecamylamine, and 10 atropine. Voltage-activated sodium channels were blocked with $1 \mu \mathrm{M}$ 
tetrodotoxin (TTX). Cav currents were antagonized with $1.8 \mathrm{~mm}$ cobalt (Goldberg et al., 2012). The acute effects of solution exchanges or drug applications were measured $\geq 5 \mathrm{~min}$ after wash on. TTX was obtained from Alomone Labs. Calcium indicators (fluo-4) were acquired from Invitrogen. The other drugs and reagents were obtained from Tocris Bioscience or Sigma-Aldrich.

Data and statistical analysis. Electrophysiological data were analyzed and curve fitting was done using custom-made code on custom-made (Winfluor, Dr. John Dempster, University of Strathclyde; NUPver, Nicholas Schwarz, Northwestern University; oscilloscope, Dr. Charles Wilson, University of Texas at San Antonio) and commercial (Matlab, Mathworks; RRID:SCR_001622) software. The two-tailed Wilcoxon rank-sum test (RST) was used to test for changes of medians in two independent sample comparisons. The two-tailed Wilcoxon signed-rank test was used to test for changes of medians in matched-paired comparisons. ANCOVA was used to compare (1) the availability of voltageactivated sodium (Nav) channels in A53T-SNCA versus wild-type mice by measuring the dependence of maximal $\mathrm{dV} / \mathrm{dt}$ of the action potential voltage trajectory on action potential number during a burst of 10 spikes; and (2) the percent change in Kv4.3 currents as a function of time since the beginning of intracellular dialysis with GSH. The null hypotheses were rejected if the $P$ values were $<0.05$.

\section{Results}

\section{Autonomous firing rates of DMV neurons are unchanged in} A53T-SNCA mice

Immunohistochemical studies of coronal sections of the caudal brainstem revealed expression of mutant human $\alpha$-synuclein in the DMV of transgenic A53T-SNCA mice, but not in their corresponding wild-type littermates (Fig. 1). Double staining for ChAT demonstrated that the mutant human protein is expressed in somata of DMV neurons (Fig. 1B), and in some case even more strongly in processes other than those of neuronal cell bodies (Fig. 1C, left). Nevertheless, quantitative optical density measurements reveal a 45 -fold increase in the mean $\alpha$-synuclein immunointensity in the somata of cholinergic motoneurons of the DMV from A53T-SNCA mice relative to wild-type mice (Fig. 1C, right), meaning that there is significant overexpression of $\alpha$-synuclein in cholinergic DMV neurons only in the transgenic mouse. DMV neurons from either wild-type or A53T-SNCA mice recorded in the loose-patch or cell-attached modes (which do not disrupt the intracellular milieu and therefore preserve the autonomous firing patterns) in the presence of a mixture of glutamatergic, GABAergic, and cholinergic receptor antagonist demonstrated that the autonomous firing rate of DMV neurons was unaffected by ASOX (wild-type median: 1.21 spikes/s, $n=$ 28; A53T-SNCA median: 1.28 spikes/s, $n=21$; $p>0.99$, RST; Fig. $2 A)$. The dominant inward current activated in the subthreshold voltage range that drives autonomous pacemaking in DMV neurons is the persistent sodium current, which is significantly larger than the Cav1 calcium or the hyperpolarization/cyclic nucleotide gated cation $(\mathrm{HCN})$ currents in these neurons (Goldberg et al., 2012). Direct measurement of the TTX-sensitive persistent sodium current in these neurons in A53T-SNCA mice ( $n=7$ neurons) versus wild-type mice ( $n=7$ neurons) demonstrated that it did not differ between the genotypes $(p>0.6$, ANCOVA; Fig. $2 B)$. This finding can therefore explain the lack of difference in the autonomous firing rates of DMV neurons between the two genotypes.

To determine whether ASOX might affect other aspects of the excitability of DMV neurons, we recorded their firing patterns in the whole-cell configuration. DMV neurons fired autonomously in the whole-cell configuration (Fig. 2C, left, black trace), as previously reported (Goldberg et al., 2012; Cooper et al., 2015). Long hyperpolarizing currents elicited the typical voltage sag,
A

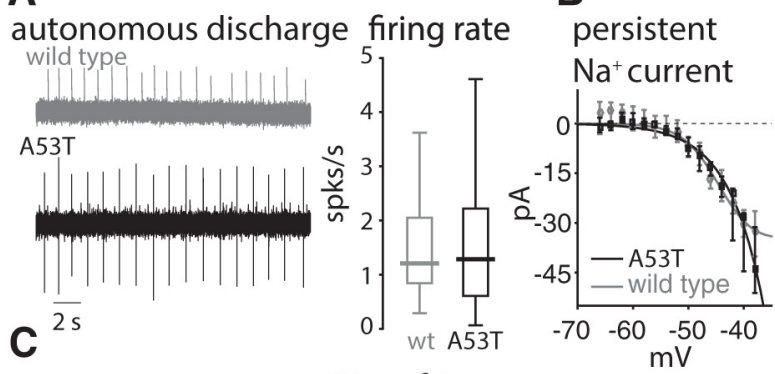

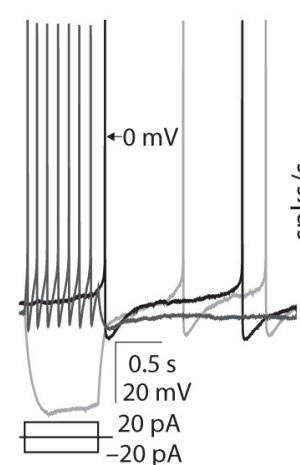

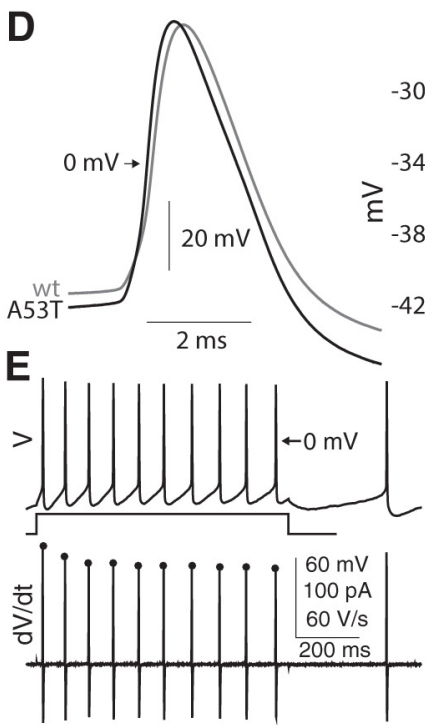

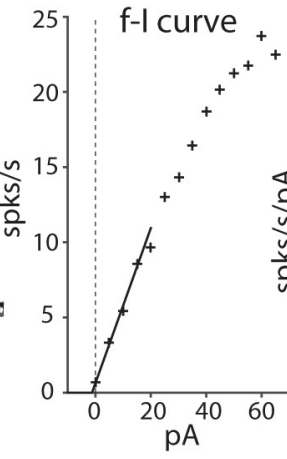

threshold spike width

gain of f-I curve

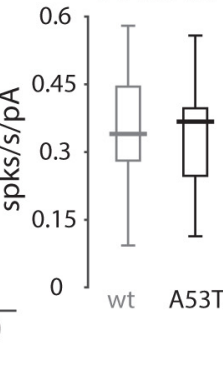

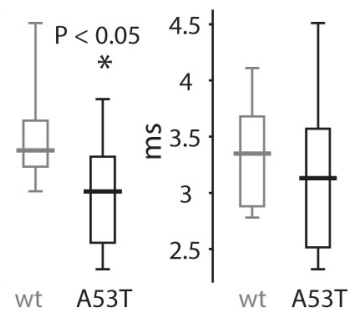

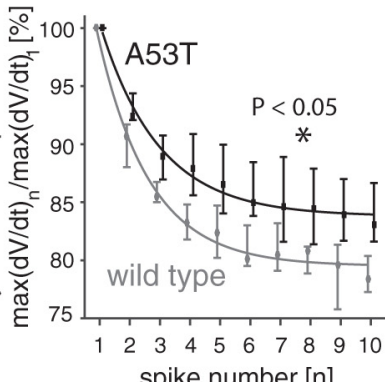

Figure 2. Firing properties of DMV neurons in A53T-SNCA mice. A, Left, Loose-patch recording of autonomous firing of DMV neurons in wild-type (wt; gray trace) and A53T-SNCA mice. Right, Distribution of autonomous DMV neurons firing rates in both genotypes (wild type: $n=$ 28 neurons; A53T-SNCA: $n=21$ neurons). $\boldsymbol{B}$, Measurement of the persistent TTX-sensitive current in DMV neurons in response to long subthreshold voltage pulses reveals no difference between wild-type (gray, $n=7$ neurons) and A53T-SNCA (black, $n=7$ neurons) mice. C, Left, Whole-cell recording of the autonomous firing pattern (black trace) or in response to depolarizing (dark gray trace) and hyperpolarizing (light gray trace) pulses in a DMV neuron from an A53T-SNCA mouse. Middle, $f-I$ curve of the cell depicted on the right, using the reciprocal of the first interspike interval. Straight line, Fit of the initial slope (gain) of the $f-I$ curve. Right, Distribution of the gain of $f-I$ curves from wild-type $(n=25)$ and A53T-SNCA $(n=21)$ neurons. $\boldsymbol{D}$, Left, DMV neuron action potential waveform (during autonomous firing) in wild-type (gray trace, $n=10$ neurons) and A53T-SNCA mice (black trace, $n=16$ neurons). Right, Distributions of voltage threshold and width of action potentials in DMV neurons from wild-type (gray, $n=$ 10 neurons) and A53T-SNCA mice (black, $n=15$ neurons). $\boldsymbol{E}$, Left, Voltage ( $\boldsymbol{V}$ and derivative of voltage (dV/dt), trajectories in response to current injections that elicit 10 action potentials in an $800 \mathrm{~ms}$ interval. Distribution of the maximal $\mathrm{dV} / \mathrm{dt}$ as a function of action potential number ( $n$ ) normalized by the max $\mathrm{dV} / \mathrm{dt}$ value of the first action potential reveals that Nav-channel availability is significantly larger for the A53T-SNCA mice (wild type: $n=19$ neurons; A53T-SNCA: $n=19$ neurons). In $\boldsymbol{B}$ and $\boldsymbol{E}$, the medians of each measurement are presented with confidence intervals given by $50 \% \times(1 \pm 1 / \mathrm{V} k)$ percentiles where $k$ is the sample size. 
attributable to the HCN current, followed by the slow ramp up to voltage threshold, attributable to the A-type Kv4.3 potassium current (Fig. 2C, left, light gray trace). Long depolarizing currents sped up the cells and elicited a slow afterhyperpolarization (sAHP, Fig. 2C, left, dark gray trace; Sah and McLachlan, 1991; Hocherman et al., 1992; Goldberg et al., 2012). Measurement of the frequency-intensity $(f-I)$ curve, using the reciprocal of the first interspike interval (Fig. $2 C$, middle), demonstrated that the firing rate initially rose linearly with current. However, the initial slope (gain) of the $f-I$ curve did not differ between wild-type and A53T-SNCA neurons (wild-type median: 0.340 spikes/s/pA, $n=$ 25; A53T-SNCA median: 0.367 spikes/s/pA, $n=21 ; p>0.85$, RST; Fig. 2C, right).

\section{Availability of Nav channels is elevated in A53T-SNCA mice}

Measurement of the trajectory of individual action potentials revealed that the voltage threshold of DMV neurons was slightly hyperpolarized in the A53T-SNCA mice (wild-type median: $-36.2 \mathrm{mV}, n=10$; A53T-SNCA median: $-38.5 \mathrm{mV}, n=16 ; p<$ 0.04 , RST), whereas the width of the action potential was unchanged (amplitude $>70 \mathrm{mV}$; wild-type median: $3.35 \mathrm{~ms}, n=10$; A53T-SNCA median: $3.13 \mathrm{~ms}, n=15 ; p>0.35$, RST; Fig. 2D). A hyperpolarized action potential voltage threshold is usually indicative of a higher degree of Nav-channel availability, which is also echoed in a steeper rate of rise of voltage $(\mathrm{dV} / \mathrm{dt})$ during the action potential upswing (Fig. $2 \mathrm{D}$, left). A more sensitive biophysical measure of Nav-channel availability is the reduction in the maximal $\mathrm{dV} / \mathrm{dt}$ during a train of action potentials (Hondeghem, 1978; Strichartz and Cohen, 1978; Fleidervish et al., 2008). Applying this technique, we found that the maximal $\mathrm{dV} / \mathrm{dt}$ undergoes a smaller reduction during a train of action potentials in DMV neurons from A53T-SNCA mice compared with DMV neurons from wild-type littermate mice (wild-type $n=19$ cells; A53T-SNCA $n=19$ cells; $p<0.04$, ANCOVA; Fig. $2 E$ ).

\section{ASOX prevents oxidative dysfunction of Kv4.3 channels in DMV neurons}

Because Nav-channel availability is elevated in reduced environments (Fukuda et al., 2005; Nakajima et al., 2010), our finding raises the intriguing possibility that the cytosol of DMV neurons in A53T-SNCA neurons is actually reduced relative to that of wild-type mice. If this is true, it could mean that Kv4.3 channels that give rise to a prominent A-type potassium current in DMV neurons (Yarom et al., 1985; Sah and McLachlan, 1992; Cooper et al., 2015) do not suffer the same oxidative impairment that reduces their amplitude in SN dopamine neurons in A53T-SNCA mice (Subramaniam et al., 2014). Immunohistochemical studies of Kv4.3 expression revealed strong expression in the DMV of both wild-type and A53T-SNCA mice (Fig. 3A). In contrast to SN dopamine neurons, where the Kv4.3-mediated A-type currents were impaired in the A53T-SNCA mice relative to the wild-type mice (Subramaniam et al., 2014), we found that Kv4.3 currents in DMV neurons from A53T-SNCA and wild-type mice showed no differences in amplitude (calculated by fitting a sigmoidal to the peak current as a function of voltage; wild-type median: $947 \mathrm{pA}$, $n=9$ cells; $A 53 T-S N C A$ median: $1171 \mathrm{pA}, n=9$ cells; $p>0.86$, RST; data not shown) or voltage-dependent gating (Fig. $3 B$ ).

In $\mathrm{SN}$ dopamine neurons, intracellular dialysis of the antioxidant GSH (10 mM) rescued the impaired Kv4.3-mediated A-type currents in the A53T-SNCA mice (Subramaniam et al., 2014). Surprisingly, we found that intracellular dialysis of GSH increased the amplitude of the A-type currents in wild-type DMV neurons by $>60 \%$ ( $n=6$ cells, Fig. $3 C$, gray marks), which is indicative of a reversible oxidative dysfunction of Kv4.3 channels in these neurons under baseline conditions. In contrast, we found no evidence for oxidative dysfunction of Kv4.3 channels in DMV neurons from A53T-SNCA mice, because intracellular dialysis of $10 \mathrm{~mm}$ GSH did not alter the amplitude of A-type currents $(n=7$ cells, Fig. $3 C$, black marks). The responses in the two genotypes to GSH dialysis differed significantly from each other $\left(p<10^{-9}\right.$, ANCOVA).

\section{Basal mitochondrial oxidative stress is reduced in DMV neurons in A53T-SNCA mice}

The fact that GSH failed to rescue of Kv4.3 currents suggests that oxidative stress is reduced in DMV neurons from A53T-SNCA mice. To monitor oxidative levels directly in DMV neurons, we stereotaxically injected an adeno-associated virus serotype 9 harboring the mitochondrial-targeted, redox-sensitive GFP expression construct (AAV9-CMV-mito-roGFP) into the DMV of 7-11-month-old A53T-SNCA mice and their littermate controls (Fig. 4A). Two weeks following transfection, we used two-photon laser scanning microscopy (2PLSM) to image the level of mito-roGFP fluorescence in vagal motoneurons in coronal slices of DMVs. The relative oxidization level of each neuron was calibrated at the end of each experiment by comparing it to the levels of fluorescence attained with strong reducing and oxidizing agents (Goldberg et al., 2012). The distribution of values-estimated using viral delivery of mito-roGFP — of basal mitochondrial oxidative stress in DMV neurons of wild-type mice matched the values estimated from transgenic mice expressing mito-roGFP in DMV neurons under the CMV promoter (Fig. 4B, dotted boxplot; Goldberg et al., 2012). Importantly, our analysis revealed that basal mitochondrial oxidative stress in DMV neurons was significantly diminished in the A53T-SNCA mice (wild-type median: $40.4 \%, n=7$ cells from $N=4$ mice; $A 53 T$-SNCA median: $8.6 \%, n=10$ cells from $N=4$ mice; $p<$ 0.02, RST; Fig. $4 B)$.

\section{Downregulated Cav currents reduced activity-dependent calcium levels in DMV neurons from A53T-SNCA mice}

The degree of basal mitochondrial oxidative stress is dictated in DMV neurons (Goldberg et al., 2012) as well as in other neurons vulnerable in PD (Guzman et al., 2010; Surmeier et al., 2011; Sanchez-Padilla et al., 2014) by calcium influx via Cav channels during autonomous pacemaking. Therefore, finding a drastic reduction in basal mitochondrial oxidative stress in A53T-SNCA mice predicts reduced activity-dependent calcium levels and Cav currents in these mice relative to wild-type control mice. To compare activity-dependent intracellular calcium levels in DMV neurons from wild-type and A53T-SNCA mice, we used wide-field somatic calcium imaging of DMV neurons loaded with $50 \mu \mathrm{M}$ of the fluorescent indicator, fluo-4 (Fig. 5A). Because the concentration of intracellular calcium depends on the neurons' firing rates (Goldberg et al., 2012), we measured the increase in $\Delta F / F_{0}$ while injecting a series of long current pulses to first silence and then activate the cells progressively faster (Fig. 5B; Cooper et al., 2015). As shown previously (Goldberg et al., 2012; Cooper et al., $2015)$, there is a robust linear relationship between $\Delta F / F_{0}$ and the neuron's firing rate (Fig. $5 \mathrm{C}$ ). The slope of this linear relationship was significantly reduced by $\sim 25 \%$ in $A 53 T-S N C A$ relative to wild-type mice [wild-type median: $0.104\left(\Delta F / F_{0}\right) /($ spikes/s), $n=$ 19 cells from $N=3$ mice; A53T-SNCA median: $0.078\left(\Delta F / F_{0}\right) /$ (spikes/s), $n=19$ cells from $N=3$ mice; $p<0.05$, RST; Fig. $5 C$ ], indicating that individual spikes contribute less to the basal calcium levels in DMV neurons in the A53T-SNCA relative to wildtype mice. This reduction in somatic calcium levels suggests that 

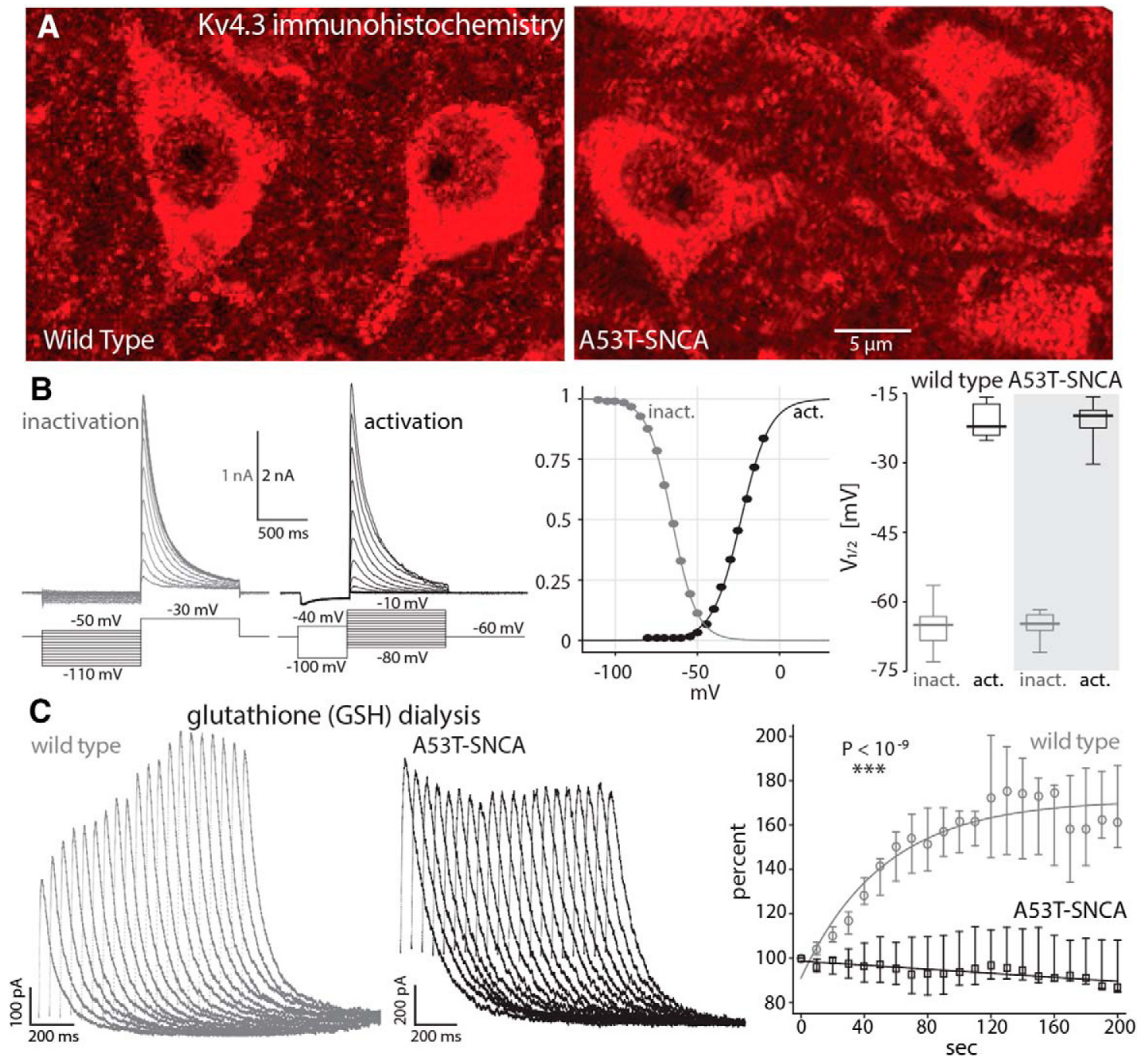

Figure 3. Glutathione (GSH) rescues Kv4.3 currents in DMV neurons in the wild-type but not the A53T-SNCA mice. A, Kv4.3 immunohistochemistry in DMV neurons in wild-type and A53T-SNCA mice. $\boldsymbol{B}$, Measurement of transient outward (A-type) potassium currents in whole-cell voltage-clamp recordings reveals that activation and inactivation of Kv 4.3 channels is unchanged in $A 53 T$-SNCA mice ( $n=9$ neurons) relative to wild-type controls ( $n=9$ neurons). C, Left, A-type current traces (in response to voltage steps to $-40 \mathrm{mV}$ as in the "activation" traces in $\boldsymbol{B}$ ) during intracellular dialysis of $10 \mathrm{~mm}$ GSH reveal a rescue of the current in the wild-type (gray traces) but not the A53T-SNCA (blacktraces) mice. The traces are measured at 10 sintervals. Right, Graph showing the relative change of the median A-type potassium current during GSH dialysis on DMV neurons from control (gray circles, $n=6$ neurons) and A53T-SNCA (black squares, $n=7$ neurons) mice, respectively. The lines represent an exponential fit of median control data and a linear fit for the median A53T-SNCA data, respectively. Confidence intervals are calculated as in Figure 2.

calcium currents via Cav channels, which are activated during spiking, are reduced in DMV neurons from A53T-SNCA mice relative to wild-type mice. To test this hypothesis, we measured cobalt-sensitive calcium currents with fast voltage ramps (240 $\mathrm{mV} / \mathrm{s}$ ), and found that the mean Cav currents (wild-type, $n=6$ cells; A53T-SNCA, $n=12$ cells) were indeed significantly smaller in 3-8-month-old (nominally presymptomatic) A53T-SNCA mice (the peak activation was reduced by more than half; Fig. $6 A$ ). In addition, the mean current waveform suggested that the voltage gating of the Cav current was shifted to more depolarized voltages (Fig. 6A). To quantify this effect at a cell-by-cell level, we estimated the half activation of the Cav current in each cell individually, and found that there was a significant rightward shift in the activation curve of Cav currents in the A53T-SNCA mice (wild-type median: $-10.7 \mathrm{mV}, n=6$ cells; $A 53 T$-SNCA median: $-6.1 \mathrm{mV}, n=10$ cells; $p<0.025$, RST; Fig. $6 B$ ). Measurement of the average currents (data not shown) and half activation voltages in DMV neurons from 12-15-month-old mice revealed the same rightward shift (wild-type median: $-13.3 \mathrm{mV}, n=4$ cells from
$N=3$ mice; $A 53 T$-SNCA median: $-4.7 \mathrm{mV}, n=4$ cells from $N=3$ mice; $p<0.03$, RST; Fig. $6 B)$.

A rightward shift in the Cav activation curve implies that with each action potential there should be fewer channel openings and therefore a smaller flux of calcium ions in the A53T-SNCA mice. We used the action-potential clamp technique (Llinás et al., 1982; Bean, 2007; Goldberg et al., 2012) to estimate the calcium charge fluxed with each action potential (as the integral beneath the curve of the cobalt-sensitive calcium action current; Fig. $6 C$ ), and indeed found a reduction in this charge in the A53T-SNCA mice (wild-type median: $2.36 \mathrm{pC}, n=6$ cells; A53T-SNCA median: $1.49 \mathrm{pC}, n=16$ cells; $p<0.04$, RST; Fig. $6 C$, inset), compatible with the reduction in the spike-triggered increases in calcium levels reported above (Fig. 5).

Cav1.2 and Cav2.3 $\alpha_{1}$ subunit transcripts are downregulated in A53T-SNCA mice

DMV neurons express a variety of Cav channels whose $\alpha_{1}$ subunits are mostly Cav1.2 or Cav2.3 (Cooper et al., 2015). 
A

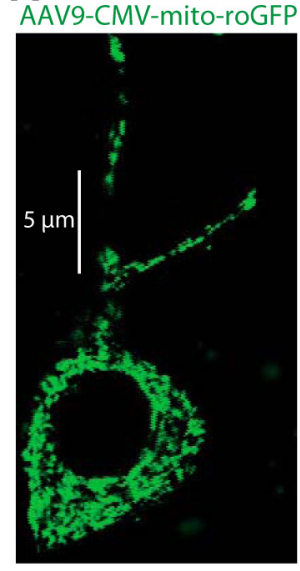

B

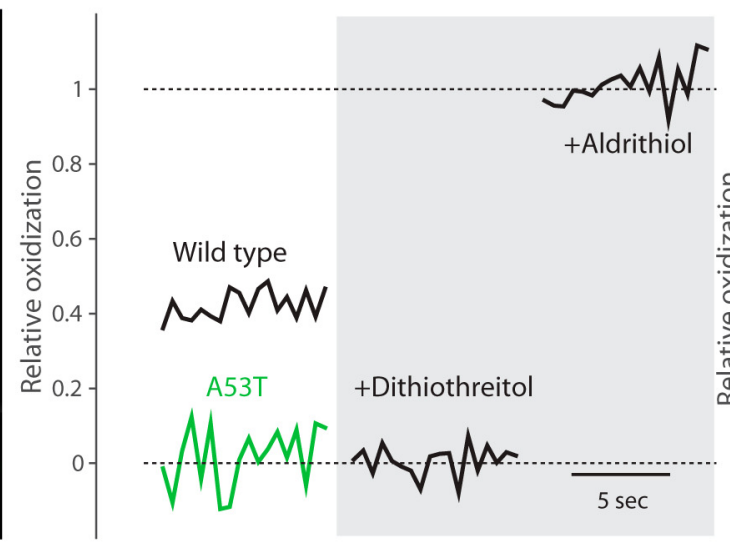

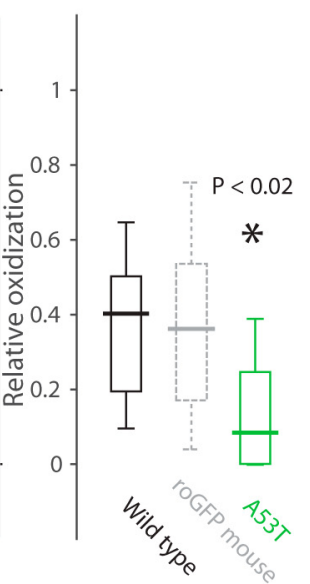

Figure 4. Basal mitochondrial oxidative stress is reduced in DMV neurons from A53T-SNCA mice. A, Confocal image of DMV neuron from a wild-type mouse expressing mito-roGFP 2 weeks after viral transfection with the AAV9-CMV-mito-roGFP. B, The relative oxidization was estimated by measuring the resting fluorescence of the mitochondria using 2PLSM (in the somata surrounding the nucleus) relative to post-treatment with strong reducing ( $2 \mathrm{~mm}$ dithiothreitol) and oxidizing ( $400 \mu \mathrm{m}$ aldrithiol) agents. Basal mitochondrial oxidative stress is reduced in DMV neurons from A53T-SNCA mice (green boxplot, $n=10$ neurons) relative to DMV neurons from wild-type mice (black boxplot, $n=7$ neurons). The distribution of relative oxidization in DMV neurons from transgenic mice expressing mito-roGFP under the CMV promoter (dotted gray boxplot; Goldberg et al., 2012) is very similar to the distribution measured from the virally transfected wild-type mice in the present study.
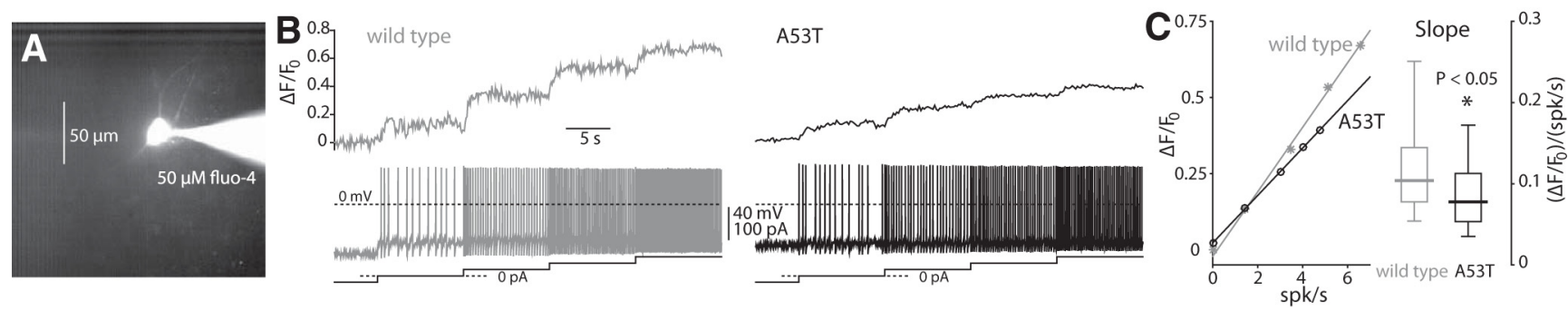

Figure 5. Spike-dependent calcium levels are reduced in DMV neurons in A53T-SNCA mice. $A, A$ DMV neuron loaded with $50 \mu \mathrm{m}$ fluo-4 for wide-field somatic calcium imaging. $\boldsymbol{B}, \mathrm{A}$ sequence of 10-s-long current pulses from $-20 \mathrm{pA}$ to $+60 \mathrm{pA}$, induces spiking at progressively higher rates in DMV neurons from wild-type (left) and A53T-SNCA (right) mice, which are accompanied by increases in somatic calcium levels, as measured by increased $\Delta F / F_{0}$. C, Left, The linear dependence of $\Delta F / F_{0}$ on firing rate in the DMV neuron depicted in $\boldsymbol{B}$ (average of final $5 \mathrm{~s}$ during each current step). Right, The distribution of the slope $\left[\left(\Delta F / F_{0}\right) /(\right.$ spikes $\left./ s)\right]$ of the linear relationship in A53T-SNCA ( $n=19$ neurons) and wild-type $(n=19$ neurons) mice demonstrate that activity-dependent calcium levels are significantly reduced in A53T-SNCA relative to wild-type mice.

Both these channels activate at slightly more hyperpolarized potentials than the rest of the high-voltage-activated Cav2 channels (Regan et al., 1991; Tottene et al., 1996; Magistretti et al., 2000; Lipscombe et al., 2004). We therefore hypothesized that the rightward shift, as well as the overall reduction in the current (Fig. 6A), could arise simply from a reduced expression levels of these subunits in the ASOX mice. Tissue level quantitative RT-PCR analysis in the DMV (normalized to neuronal markers) indeed revealed that transcripts of these two $\alpha_{1}$ subunits were significantly downregulated in the A53T-SNCA mice, while those of other Cav1 and Cav2 $\alpha_{1}$ subunits were not (Fig. 6D).

\section{Discussion}

\section{$\alpha$-Synuclein and selective vulnerability in PD}

The causal role of $\alpha$-synuclein in the pathogenesis of familial and sporadic PD has been firmly established (Goedert et al., 2013). Analysis of rare familial forms of PD identified either causal dominant mutations in the gene coding for $\alpha$-synuclein (e.g., $A 53 T$ $S N C A$ ) or multiplications of the SNCA gene locus (Devine et al., 2011). In addition, genome-wide association studies in large cohorts of common sporadic forms of PD have demonstrated highly significant $\left(p<10^{-60}\right)$ associations between increased risk for PD and certain single nucleotide polymorphisms (SNPs) within SNCA (Simón-Sánchez et al., 2009). These SNPs are associated with increased $\alpha$-synuclein expression, which is in line with Mendelian forms of PD, where an increased $\alpha$-synuclein load drives the disease process. There is also consensus that aggregation of $\alpha$-synuclein to toxic fibrils - enhanced by load, mutations, and protein modifications-is a crucial step in PD pathogenesis (Farrer, 2006).

What is less understood is how these $\alpha$-synuclein-related processes might manifest within the unique cellular context of each neuronal population vulnerable in PD. For example dopamine, its metabolites, and its transporters might exacerbate the toxic effect of $\alpha$-synuclein (Tabrizi et al., 2000; Lotharius and Brundin, 2002; Wersinger and Sidhu, 2003; Sidhu et al., 2004; Sulzer, 2010; Oaks et al., 2013; Jain and Bhat, 2014; Jinsmaa et al., 2014; Tavassoly et al., 2014)—interactions unique to dopaminergic neurons. Neuromelanin may also interact with $\alpha$-synuclein deleteriously (Dias et al., 2013; Xu and Chan, 2015), a process that may be relevant to LC neurons, as well. In summary, it is possible that cell-specific interactions predispose various neuronal types to divergent cell fates, which could explain why highly vulnerable (e.g., SN dopamine or LC) neurons massively degenerate in re- 
A average cobaltsensitive currents

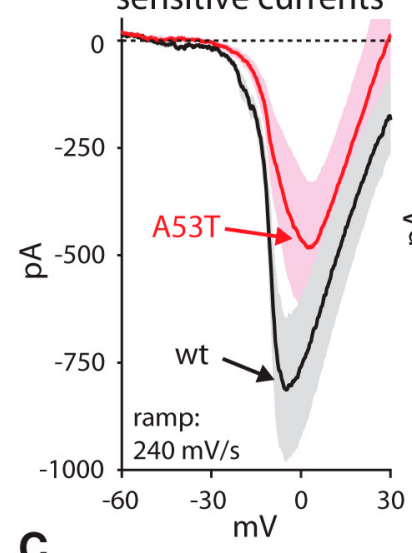

C

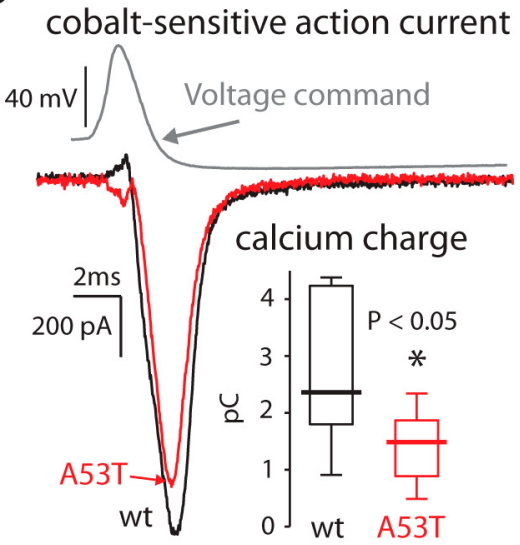

B half activation voltage $\left(V_{1 / 2}\right)$ of cobalt-sensitive currents
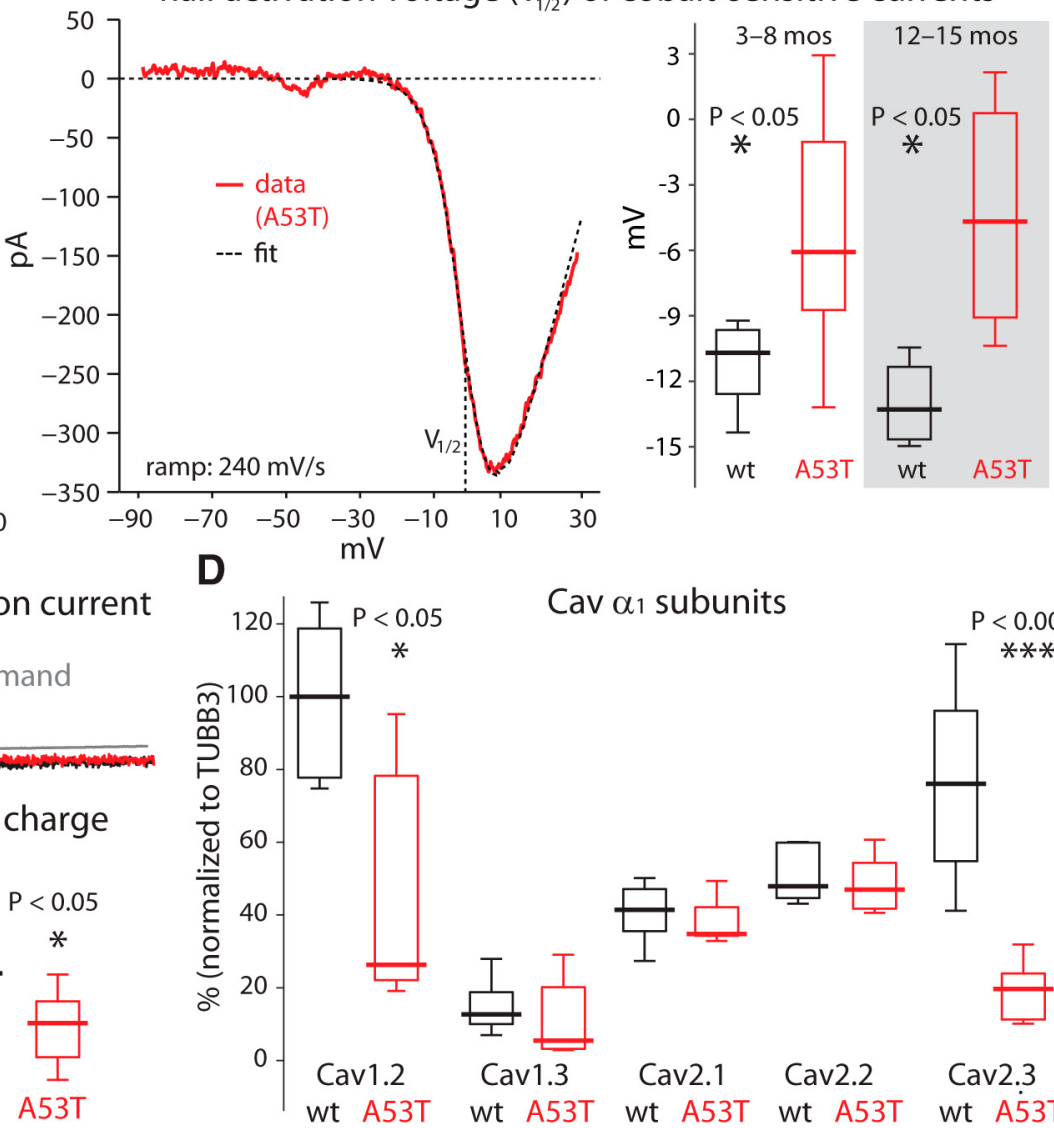

Cav $\alpha_{1}$ subunits

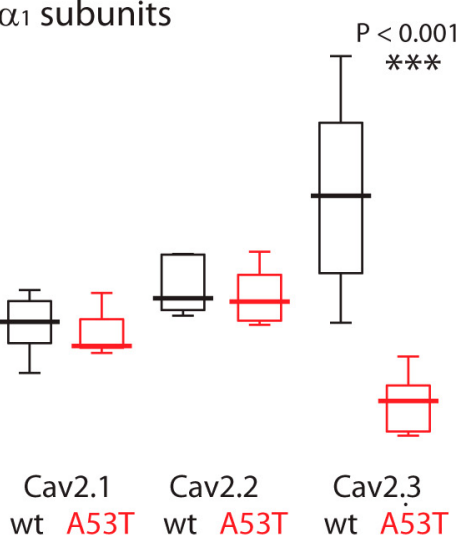

Figure 6. Cav channels are downregulated in DMV neurons in A53T-SNCA mice. $\boldsymbol{A}$, Mean cobalt-sensitive Cav currents evoked with a voltage ramp in 3-month-old A53T-SNCA mice (red, $n=12$ neurons) is reduced and shifted to the right relative to littermate wild-type (wt) mice (black, $n=6$ neurons). $\boldsymbol{B}$, Left, Fitting activation curves to individual cobalt-sensitive current measurements yields their half-activation voltage $\left(V_{1 / 2}\right)$. Right, Distribution of half-activation voltages reveals a significant depolarization both in 3-8-month-old presymptomatic (wild type, $n=6$ neurons; A53T-SNCA, $n=10$ neurons) and 12-15-month-old symptomatic mice (wild type, $n=4$ neurons; $A 53 T$-SNCA, $n=4$ neurons). $C$, Cobalt-sensitive calcium action current evoked during an action potential voltage clamp is reduced leading to a significant reduction in the calcium charge fluxed during the clamp (inset; wild type, $n=6$ neurons; $A 53 T$-SNCA, $n=16$ neurons). $\boldsymbol{D}$, Neuronal $C$ av channel $\alpha$ subunit mRNA expression normalized to TUBB3 in microdissected DMV from A53T-SNCA mice relative to wild-type controls (Cooper et al., 2015). The expression level is expressed in percentages of the median value of expression of Cav1.2 $\alpha_{1}$ subunit mRNA in wild-type mice (leftmost boxplot).

sponse to $\alpha$-synucleinopathies while more resistant (e.g., DMV) neurons do so to a lesser extent.

$\alpha$-Synuclein and oxidative dysfunction in vulnerable neurons Mouse models, in which the load of mutant or wild-type $\alpha$-synuclein expression can be experimentally regulated, can prove useful in addressing the question of cell-type-specific effects of $\alpha$-synuclein. Nevertheless, few studies have looked at the physiological changes in defined neuronal populations in response to ASOX. Two recently published in vivo studies on SN dopamine neurons in ASOX mouse models offer conflicting results. Using a transgenic mouse model overexpressing human wild-type $\alpha$-synuclein on a background of a C57BL $6 \alpha$-synuclein knock-out mouse, Janezic and colleagues found $\sim 30 \%$ reduction of in vivo mean firing frequencies in old mice (18-22 months), where a significant loss of SN dopamine neurons was already present (Janezic et al., 2013). In contrast, Subramaniam and colleagues reported a twofold increase of in vivo mean firing frequencies in middle-aged (6-10 months) but not younger ( 3 months) adults (Subramaniam et al., 2014). The latter study also found that oxidative dysfunction of an A-type (Kv4.3) potassium channel was an important element of $\alpha$-synucleininduced hyperactivity. This finding is in agreement with other, more acute in vitro studies showing that $\alpha$-synuclein enhances oxidative stress (Hsu et al., 2000; Sherer et al., 2001; Dryanovski et al., 2013).

In both $\mathrm{SN}$ dopamine neurons and vagal motoneurons, substantial calcium influx during autonomous pacemaking is sufficient to generate basal mitochondrial oxidative stress (Guzman et al., 2010; Goldberg et al., 2012). Multiple lines of evidence support the hypothesis that ASOX should elevate oxidative stress by elevating calcium influx. For example, ASOX may directly potentiate Cavs (Adamczyk and Strosznajder, 2006; Hettiarachchi et al., 2009) or may increase calcium influx by elevating autonomous firing rates, which will invariably increase activitydependent calcium influx via Cav channels (Dryanovski et al., 2013; Subramaniam et al., 2014). Alternatively, neurons possess several homeostatic mechanisms controlling both synaptic and intrinsic excitability to maintain their physiological firing range even when challenged with stressors (Turrigiano, 2011; Dias et al., 2013), meaning that elevation of firing could be prevented and calcium currents could be kept at bay. Indeed, even SN dopamine neurons mount a partial homeostatic response to $\alpha$-synuclein-induced hyperactivity by elevating expression and membrane delivery of Kv4.3 channels (Subramaniam et al., 2014). 
Our findings suggest that DMV neurons, in contrast to SN dopamine neurons, are able to mount a successful homeostatic response to significant overexpression of $\alpha$-synuclein (as validated by immunohistochemistry), and that these neurons are able to maintain their normal autonomously generated firing rates in vitro both in young (nominally presymptomatic) and in older adult mice. Interestingly, a recent study has reported a reduction in the autonomous firing rate of DMV neurons from aging triple synuclein knock-out $\left(\alpha \beta \gamma^{-/-}\right)$mice (Machhada et al., 2015). Our data demonstrate that the biophysical mechanism of the homeostatic response that maintains the firing rate in ASOX DMV neurons involved both Kv4.3 A-type channels, which are prominent determinants of DMV neuron firing rates (Cooper et al., 2015), and Cav channels, as explained presently.

Unlike its effect on SN dopamine neurons, GSH dialysis did not rescue Kv4.3-channel activity in DMV neurons in the A53TSNCA mouse, indicating that the Kv4.3 activity was not impaired. Moreover, GSH dialysis demonstrated that Kv4.3 channels were impaired in wild-type DMV neurons, implying that not only did ASOX not exacerbate oxidative stress; rather it significantly alleviated it in the A53T-SNCA mice. Furthermore, direct visualization with 2PLSM of basal mitochondrial oxidative stress in DMV neurons with the virally delivered mito-roGFP reporter demonstrated that indeed oxidative stress was all but abolished in these neurons in the A53T-SNCA mice.

\section{Oxidative stress and calcium homeostasis in vulnerable neurons}

Given our previous study on the role of activity-dependent calcium influx via Cav channels in generating basal mitochondrial oxidative stress in DMV neurons (Goldberg et al., 2012), we looked for changes in calcium signaling in these cells. We identified significantly smaller mean Cav currents in A53T-SNCA compared with wild-type DMV neurons as early as 3 months after birth, and at least until 15 months. We also noted that the voltagedependence of the mean Cav currents in A53T-SNCA DMV neurons, to which several Cav-channel subtypes-known to be coexpressed in DMV neurons (Cooper et al., 2015) — contribute. These reduced calcium currents also lead to measurable reductions in activity-dependent cytosolic calcium levels in A53TSNCA DMV neurons. Comparative quantitative RT-PCR of the microdissected DMV nucleus demonstrated significantly lower mRNA levels of neuronal Cav1.2 and Cav2.3 $\alpha_{1}$ subunits in A53T-SNCA compared with wild-type mice. If translated into a matching reduction of functional Cav1.2 and Cav2.3 channel complexes, this result explains the observed reduction and apparent rightward shift of the global Cav currents (Regan et al., 1991; Tottene et al., 1996; Magistretti et al., 2000; Lipscombe et al., 2004).

In two recent studies (Goldberg et al., 2012; Cooper et al., 2015), we characterized the specific effect of various Cav-channel subunits on the autonomous firing of DMV neurons. We found that while Cav1.3 channels can speed up pacemaking, Cav2.2 and Cav1.2 channels slow down pacemaking presumably via their coupling to the small-conductance calcium-activated potassium current, and the current underlying the sAHP, respectively. Of these three subunits, only Cav1.2 is downregulated in A53TSNCA DMV neurons, which might be expected to speed up their autonomous firing rate. However, the role of Cav1.2 channels was demonstrated by a paired comparison within individual DMV neurons of the firing rate before and after complete block of Cav1 currents (with $5 \mu \mathrm{M}$ nifedipine; Cooper et al., 2015). Therefore, it is possible that in the current study when comparing
A53T-SNCA versus wild-type DMV neurons, the expected small effect of the downregulation of Cav1.2 channels on the autonomous firing rate of the former population (which was estimated as an increase of the firing rate by 0.25 spikes/s), might have been lost within the normal firing rate variability of DMV neurons in both populations.

\section{Antioxidative response in vagal motoneurons overexpressing $\alpha$-synuclein}

In essence, we discovered that DMV neurons initiated an antioxidative response upon chronic challenge with mutant $\alpha$-synuclein without obvious impairment of their function - at least vis-à-vis in vitro pacemaking. This might explain why DMV neuronsalthough a locus of very early $\alpha$-synucleinopathy in PD—do not degenerate at such an extent as the highly vulnerable SN dopamine neurons, at least based on the small number of quantitative human postmortem studies in the DMV (Eadie, 1963; Seidel et al., 2010). The unexpected and overshooting protective remodeling of redox signaling in DMV neurons might be executed on multiple levels ranging from changes in activity-mediated calcium influx, via enhanced calcium extrusion and buffering, to orchestrated transcriptional responses leading to an enhancement of endogenous antioxidative defense mechanisms [e.g., activation of the nuclear erythroid 2-related factor 2-antioxidant response element pathway, which restores GSH levels (Lim et al., 2014)]. The fact that the remodeling seems to be selective to DMV neurons may depend on their cholinergic specification, which in turn depends on the expression of brain region-specific transcription factors that influence Cav expression and that may be distinct from those present in SN dopamine neurons (Soreq, 2015). Deciphering the molecular details of this protective adaptation in DMV neurons might pave the way to novel treatments that could emulate these changes in $\mathrm{SN}$ dopamine neuron, to counter the tendency of ASOX to exacerbate their already high innate oxidative stress. Antagonizing Cav channels with brainpenetrant dihydropyridines, a treatment currently in a phase III clinical trial ("STEADY-PD III", ClinicalTrials.gov identifier: NCT02168842), already follows the putative strategy of reducing oxidative stress and slowing the degeneration of $\mathrm{SN}$ dopamine neurons via manipulation of Cav channels. When challenged with ASOX, DMV neurons appear to employ the same Cavcurrent-reducing strategy by remodeling their biophysics toward stressless pacemaking.

\section{References}

Adamczyk A, Strosznajder JB (2006) Alpha-synuclein potentiates Ca2+ influx through voltage-dependent Ca2+ channels. Neuroreport 17:18831886. CrossRef Medline

Bean BP (2007) The action potential in mammalian central neurons. Nat Rev Neurosci 8:451-465. CrossRef Medline

Bolam JP, Pissadaki EK (2012) Living on the edge with too many mouths to feed: why dopamine neurons die. Mov Disord 27:1478-1483. CrossRef Medline

Braak H, Ghebremedhin E, Rüb U, Bratzke H, Del Tredici K (2004) Stages in the development of Parkinson's disease-related pathology. Cell Tissue Res 318:121-134. CrossRef Medline

Chiu WH, Carlsson T, Depboylu C, Höglinger GU, Oertel WH, Ries V (2014) Selegiline normalizes, while l-DOPA sustains the increased number of dopamine neurons in the olfactory bulb in a 6-OHDA mouse model of Parkinson's disease. Neuropharmacology 79:212-221. CrossRef Medline

Cooper G, Lasser-Katz E, Simchovitz A, Sharon R, Soreq H, Surmeier DJ, Goldberg JA (2015) Functional segregation of voltage-activated calcium channels in motoneurons of the dorsal motor nucleus of the vagus. J Neurophysiol 114:1513-1520. CrossRef Medline 
Devine MJ, Gwinn K, Singleton A, Hardy J (2011) Parkinson's disease and $\alpha$-synuclein expression. Mov Disord 26:2160-2168. CrossRef Medline

Dias V, Junn E, Mouradian MM (2013) The role of oxidative stress in Parkinson's disease. J Parkinsons Dis 3:461-491. CrossRef Medline

Dooley CT, Dore TM, Hanson GT, Jackson WC, Remington SJ, Tsien RY (2004) Imaging dynamic redox changes in mammalian cells with green fluorescent protein indicators. J Biol Chem 279:22284-22293. CrossRef Medline

Dryanovski DI, Guzman JN, Xie Z, Galteri DJ, Volpicelli-Daley LA, Lee VM, Miller RJ, Schumacker PT, Surmeier DJ (2013) Calcium entry and $\alpha$-synuclein inclusions elevate dendritic mitochondrial oxidant stress in dopaminergic neurons. J Neurosci 33:10154-10164. CrossRef Medline

Eadie MJ (1963) The pathology of certain medullary nuclei in Parkinsonism. Brain 86:781-792. CrossRef Medline

Farrer MJ (2006) Genetics of Parkinson disease: paradigm shifts and future prospects. Nat Rev Genet 7:306-318. CrossRef Medline

Fleidervish IA, Libman L, Katz E, Gutnick MJ (2008) Endogenous polyamines regulate cortical neuronal excitability by blocking voltage-gated $\mathrm{Na}+$ channels. Proc Natl Acad Sci U S A 105:18994-18999. CrossRef Medline

Fukuda K, Davies SS, Nakajima T, Ong BH, Kupershmidt S, Fessel J, Amarnath V, Anderson ME, Boyden PA, Viswanathan PC, Roberts LJ 2nd, Balser JR (2005) Oxidative mediated lipid peroxidation recapitulates proarrhythmic effects on cardiac sodium channels. Circ Res 97:12621269. CrossRef Medline

Giasson BI, Duda JE, Quinn SM, Zhang B, Trojanowski JQ, Lee VM (2002) Neuronal alpha-synucleinopathy with severe movement disorder in mice expressing A53T human alpha-synuclein. Neuron 34:521-533. CrossRef Medline

Gispert S, Del Turco D, Garrett L, Chen A, Bernard DJ, Hamm-Clement J, Korf HW, Deller T, Braak H, Auburger G, Nussbaum RL (2003) Transgenic mice expressing mutant A53T human alpha-synuclein show neuronal dysfunction in the absence of aggregate formation. Mol Cell Neurosci 24:419-429. CrossRef Medline

Goedert M (2001) Alpha-synuclein and neurodegenerative diseases. Nat Rev Neurosci 2:492-501. CrossRef Medline

Goedert M, Spillantini MG, Del Tredici K, Braak H (2013) 100 years of Lewy pathology. Nat Rev Neurol 9:13-24. CrossRef Medline

Goldberg JA, Guzman JN, Estep CM, Ilijic E, Kondapalli J, Sanchez-Padilla J, Surmeier DJ (2012) Calcium entry induces mitochondrial oxidant stress in vagal neurons at risk in Parkinson's disease. Nat Neurosci 15:14141421. CrossRef Medline

Guzman JN, Sanchez-Padilla J, Wokosin D, Kondapalli J, Ilijic E, Schumacker PT, Surmeier DJ (2010) Oxidant stress evoked by pacemaking in dopaminergic neurons is attenuated by DJ-1. Nature 468:696-700. CrossRef Medline

Hettiarachchi NT, Parker A, Dallas ML, Pennington K, Hung CC, Pearson HA, Boyle JP, Robinson P, Peers C (2009) alpha-Synuclein modulation of Ca2 + signaling in human neuroblastoma (SH-SY5Y) cells. J Neurochem 111:1192-1201. CrossRef Medline

Hocherman SD, Werman R, Yarom Y (1992) An analysis of the long-lasting after-hyperpolarization of guinea-pig vagal motoneurones. J Physiol 456: 325-349. CrossRef Medline

Hondeghem LM (1978) Validity of Vmax as a measure of the sodium current in cardiac and nervous tissues. Biophys J 23:147-152. CrossRef Medline

Hsu LJ, Sagara Y, Arroyo A, Rockenstein E, Sisk A, Mallory M, Wong J, Takenouchi T, Hashimoto M, Masliah E (2000) alpha-Synuclein promotes mitochondrial deficit and oxidative stress. Am J Pathol 157:401410. CrossRef Medline

Jain MK, Bhat R (2014) Modulation of human $\alpha$-synuclein aggregation by a combined effect of calcium and dopamine. Neurobiol Dis 63:115-128. CrossRef Medline

Janezic S, Threlfell S, Dodson PD, Dowie MJ, Taylor TN, Potgieter D, Parkkinen L, Senior SL, Anwar S, Ryan B, Deltheil T, Kosillo P, Cioroch M, Wagner K, Ansorge O, Bannerman DM, Bolam JP, Magill PJ, Cragg SJ, Wade-Martins R (2013) Deficits in dopaminergic transmission precede neuron loss and dysfunction in a new Parkinson model. Proc Natl Acad Sci U S A 110:E4016-E4025. CrossRef Medline

Jinsmaa Y, Sullivan P, Gross D, Cooney A, Sharabi Y, Goldstein DS (2014) Divalent metal ions enhance DOPAL-induced oligomerization of alphasynuclein. Neurosci Lett 569:27-32. CrossRef Medline
Kordower JH, Olanow CW, Dodiya HB, Chu Y, Beach TG, Adler CH, Halliday GM, Bartus RT (2013) Disease duration and the integrity of the nigrostriatal system in Parkinson's disease. Brain 136:2419-2431. CrossRef Medline

Lewy FH (1912) Paralysis agitans. I. Pathologische Anatomie (in German). In: Handbuch der Neurologie (Lewandowski B, ed), pp 920-933. Berlin: Springer.

Lim JL, Wilhelmus MM, de Vries HE, Drukarch B, Hoozemans JJ, van Horssen J (2014) Antioxidative defense mechanisms controlled by Nrf2: state-of-the-art and clinical perspectives in neurodegenerative diseases. Arch Toxicol 88:1773-1786. CrossRef Medline

Lipscombe D, Helton TD, Xu W (2004) L-type calcium channels: the low down. J Neurophysiol 92:2633-2641. CrossRef Medline

Liss B, Franz O, Sewing S, Bruns R, Neuhoff H, Roeper J (2001) Tuning pacemaker frequency of individual dopaminergic neurons by Kv4.3L and KChip3.1 transcription. EMBO J 20:5715-5724. CrossRef Medline

Llinás R, Sugimori M, Simon SM (1982) Transmission by presynaptic spike-like depolarization in the squid giant synapse. Proc Natl Acad Sci U S A 79:2415-2419. CrossRef Medline

Lotharius J, Brundin P (2002) Impaired dopamine storage resulting from alpha-synuclein mutations may contribute to the pathogenesis of Parkinson's disease. Hum Mol Genet 11:2395-2407. CrossRef Medline

Machhada A, Ang R, Ackland GL, Ninkina N, Buchman VL, Lythgoe MF, Trapp S, Tinker A, Marina N, Gourine AV (2015) Control of ventricular excitability by neurons of the dorsal motor nucleus of the vagus nerve. Heart Rhythm 12:2285-2293. CrossRef Medline

Magistretti J, Brevi S, de Curtis M (2000) A blocker-resistant, fast-decaying, intermediate-threshold calcium current in palaeocortical pyramidal neurons. Eur J Neurosci 12:2376-2386. CrossRef Medline

Nakajima T, Davies SS, Matafonova E, Potet F, Amarnath V, Tallman KA, Serwa RA, Porter NA, Balser JR, Kupershmidt S, Roberts LJ 3rd (2010) Selective $\gamma$-ketoaldehyde scavengers protect NaV1.5 from oxidantinduced inactivation. J Mol Cell Cardiol 48:352-359. CrossRef Medline

Oaks AW, Marsh-Armstrong N, Jones JM, Credle JJ, Sidhu A (2013) Synucleins antagonize endoplasmic reticulum function to modulate dopamine transporter trafficking. PLoS One 8:e70872. CrossRef Medline

Paladini CA, Roeper J (2014) Generating bursts (and pauses) in the dopamine midbrain neurons. Neuroscience 282:109-121. CrossRef Medline

Parihar MS, Parihar A, Fujita M, Hashimoto M, Ghafourifar P (2008) Mitochondrial association of alpha-synuclein causes oxidative stress. Cell Mol Life Sci 65:1272-1284. CrossRef Medline

Paxinos G, Franklin KBJ (2004) The mouse brain in stereotaxic coordinates, 2nd ed. San Diego: Elsevier Academic.

Pissadaki EK, Bolam JP (2013) The energy cost of action potential propagation in dopamine neurons: clues to susceptibility in Parkinson's disease. Front Comput Neurosci 7:13. CrossRef Medline

Regan LJ, Sah DW, Bean BP (1991) Ca2 + channels in rat central and peripheral neurons: high-threshold current resistant to dihydropyridine blockers and omega-conotoxin. Neuron 6:269-280. CrossRef Medline

Sah P, McLachlan EM (1991) $\mathrm{Ca}(2+)$-activated K+ currents underlying the afterhyperpolarization in guinea pig vagal neurons: a role for $\mathrm{Ca}(2+)$ activated Ca2 + release. Neuron 7:257-264. CrossRef Medline

Sah P, McLachlan EM (1992) Potassium currents contributing to action potential repolarization and the afterhyperpolarization in rat vagal motoneurons. J Neurophysiol 68:1834-1841. Medline

Sanchez-Padilla J, Guzman JN, Ilijic E, Kondapalli J, Galtieri DJ, Yang B, Schieber S, Oertel W, Wokosin D, Schumacker PT, Surmeier DJ (2014) Mitochondrial oxidant stress in locus coeruleus is regulated by activity and nitric oxide synthase. Nat Neurosci 17:832-840. CrossRef Medline

Seidel K, Schöls L, Nuber S, Petrasch-Parwez E, Gierga K, Wszolek Z, Dickson D, Gai WP, Bornemann A, Riess O, Rami A, Den Dunnen WF, Deller T, Rüb U, Krüger R (2010) First appraisal of brain pathology owing to A30P mutant alpha-synuclein. Ann Neurol 67:684-689. CrossRef Medline

Seidel K, Mahlke J, Siswanto S, Krüger R, Heinsen H, Auburger G, Bouzrou M, Grinberg LT, Wicht H, Korf HW, den Dunnen W, Rüb U (2015) The brainstem pathologies of Parkinson's disease and dementia with Lewy bodies. Brain Pathol 25:121-135. CrossRef Medline

Sherer TB, Betarbet R, Greenamyre JT (2001) Pathogenesis of Parkinson's disease. Curr Opin Investig Drugs 2:657-662. Medline

Sidhu A, Wersinger C, Vernier P (2004) alpha-Synuclein regulation of the 
dopaminergic transporter: a possible role in the pathogenesis of Parkinson's disease. FEBS Lett 565:1-5. CrossRef Medline

Simón-Sánchez J, Schulte C, Bras JM, Sharma M, Gibbs JR, Berg D, PaisanRuiz C, Lichtner P, Scholz SW, Hernandez DG, Krüger R, Federoff M, Klein C, Goate A, Perlmutter J, Bonin M, Nalls MA, Illig T, Gieger C, Houlden $\mathrm{H}$ et al. (2009) Genome-wide association study reveals genetic risk underlying Parkinson's disease. Nat Genet 41:1308-1312. CrossRef Medline

Soreq H (2015) Checks and balances on cholinergic signaling in brain and body function. Trends Neurosci 38:448-458. CrossRef Medline

Strichartz G, Cohen I (1978) Letter to the editor: Vmax as a measure of GNA in nerve and cardiac membranes. Biophys J 23:153-156. CrossRef Medline

Subramaniam M, Althof D, Gispert S, Schwenk J, Auburger G, Kulik A, Fakler B, Roeper J (2014) Mutant $\alpha$-synuclein enhances firing frequencies in dopamine substantia nigra neurons by oxidative impairment of A-type potassium channels. J Neurosci 34:13586-13599. CrossRef Medline

Sulzer D (2010) Clues to how alpha-synuclein damages neurons in Parkinson's disease. Mov Disord 25 Suppl 1:S27-S31. CrossRef Medline

Surmeier DJ, Guzman JN, Sanchez-Padilla J, Goldberg JA (2011) The origins of oxidant stress in Parkinson's disease and therapeutic strategies. Antioxid Redox Signal 14:1289-1301. CrossRef Medline
Tabrizi SJ, Orth M, Wilkinson JM, Taanman JW, Warner TT, Cooper JM, Schapira AH (2000) Expression of mutant $\alpha$-synuclein causes increased susceptibility to dopamine toxicity. Hum Mol Genet 9:2683-2689. CrossRef Medline

Tavassoly O, Nokhrin S, Dmitriev OY, Lee JS (2014) Cu(II) and dopamine bind to $\alpha$-synuclein and cause large conformational changes. FEBS J 281: 2738-2753. CrossRef Medline

Tottene A, Moretti A, Pietrobon D (1996) Functional diversity of P-type and R-type calcium channels in rat cerebellar neurons. J Neurosci 16: 6353-6363. Medline

Turrigiano G (2011) Too many cooks? Intrinsic and synaptic homeostatic mechanisms in cortical circuit refinement. Annu Rev Neurosci 34:89103. CrossRef Medline

Wersinger C, Sidhu A (2003) Attenuation of dopamine transporter activity by alpha-synuclein. Neurosci Lett 340:189-192. CrossRef Medline

Xu S, Chan P (2015) Interaction between neuromelanin and alphasynuclein in Parkinson's disease. Biomolecules 5:1122-1142. CrossRef Medline

Yarom Y, Sugimori M, Llinás R (1985) Ionic currents and firing patterns of mammalian vagal motoneurons in vitro. Neuroscience 16:719-737. CrossRef Medline 